Oikos 123: 1281-1290, 2014

doi: 10.1111/oik.01526

(C) 2014 The Authors. Oikos (C) 2014 Nordic Society Oikos

Subject Editor: David Chalcraft. Accepted 27 March 2014

\title{
Leaf and stem physiological responses to summer and winter extremes of woody species across temperate ecosystems
}

\author{
Elena Granda, Christine Scoffoni, Alfredo E. Rubio-Casal, Lawren Sack and Fernando Valladares \\ E. Granda (elena.granda.f@gmail.com) and F. Valladares, Lab. Internacional de Cambio Global (LINC-Global), Depto de Biogeografia y \\ Cambio Global, Museo Nacional de Ciencias Naturales, MNCN, CSIC, Serrano 115 Dpdo., ES-28006 Madrid, Spain. FV also at: Depto \\ de Biologia y Geología, ESCET, Univ. Rey Juan Carlos, Tulipán s/n, ES-28933 Móstoles, Spain. - C. Scoffoni and L. Sack, Dept of Ecology \\ and Evolutionary Biology, Univ. of California, Los Angeles, 621 Charles E. Young Drive South, Los Angeles, CA 90095-1606, USA. \\ - A. E. Rubio-Casal, Depto de Biología Vegetal y Ecologí, Univ. de Sevilla, Ap. 1095, ES-41080 Sevilla, Spain.
}

\begin{abstract}
Winter cold limits temperate plant performance, as does summer water stress in drought-prone ecosystems. The relative impact of seasonal extremes on plant performance has received considerable attention for individual systems. An integrated study compiling the existing literature was needed to identify overall trends. First, we conducted a metaanalysis of the impacts of summer and winter on ecophysiology for three woody plant functional types (winter deciduous angiosperms, evergreen angiosperms and conifers), including data for 210 records from 75 studies of ecosystems with and without summer drought across the temperate zone. Second, we tested predictions by conducting a case study in a drought-prone Mediterranean ecosystem subject to winter freezing. As indicators of physiological response of leaves and xylem to seasonal stress, we focused on stomatal conductance $\left(g_{s}\right)$, percent loss of stem xylem hydraulic conductivity (PLC) and photochemical efficiency of photosystem II $\left(F_{\mathrm{v}} / F_{\mathrm{m}}\right)$. Our meta-analysis showed that in ecosystems without summer drought, $g_{s}$ was higher during summer than winter. By contrast, in drought-prone ecosystems many species maintained open stomata during winter, with potential strong consequences for plant carbon gain over the year. Further, PLC tended to increase and $F_{\mathrm{v}} / F_{\mathrm{m}}$ to decrease from summer to winter for most functional types and ecosystems due to low temperatures. Overall, deciduous angiosperms were most sensitive to climatic stress. Leaf gas exchange and stem xylem hydraulics showed a coordinated seasonal response at ecosystems without summer drought. In our Mediterranean site subjected to winter freezing the species showed similar responses to those typically found for ecosystems without summer drought. We conclude that winter stress is most extreme for systems without summer drought and systems with summer drought and winter freezing, and less extreme for drought-prone systems without freezing. In all cases the evergreen species show less pronounced seasonal responses in both leaves and stems than deciduous species.
\end{abstract}

Woody species in temperate forests show pronounced annual dynamics in growth and ecophysiology (Lo Gullo et al. 2005, Gulías et al. 2009, McCulloh et al. 2011, Carnicer et al. 2013, Granda et al. 2013). While the growth period tends to span from late spring to summer, followed by a dormant period from late fall to early spring, deviations from this general pattern occur depending on seasonal extreme climatic conditions. For instance, in drought-prone ecosystems, as in mediterranean-climate areas, plants may show an additional dormancy during summer (Cherubini et al. 2003). Further, seasonal extreme climate conditions may have contrasting physiological effects on different functional groups depending on their trait syndromes (Carnicer et al. 2013). In this study we tested for contrasting physiological responses for woody functional types which experience distinct seasonal extremes during summer and winter across the temperate zone.

Studies across the temperate zone commonly show reduced physiological function during the winter months due to freezing temperatures, including declines in stomatal conductance (Nardini and Salleo 2000, Hiyama et al. 2005), hydraulic function (Sperry et al. 1994, Mayr et al. 2006) and photochemical efficiency (Neuner and Pramsohler 2006, Porcar-Castell et al. 2008). However, it has been suggested that at sites with greater summer drought woody species experience lower stress during winter due to milder temperatures (Mitrakos 1980, Gulías et al. 2009), and summer would be the season with strongest reduction of physiological performance (Ogaya and Peñuelas 2003). Other studies have shown that even in drought-prone ecosystems (mainly Mediterranean ones) woody species experience a more pronounced reduction in physiological attributes during winter frosts than during summer droughts (Karavatas and Manetas 1999). An integrated study synthesizing the existing literature was needed to identify the overall trends in ecophysiological performance during summer and winter seasons. Moreover, clarifying the differences among plant functional types would be of great value for understanding 
and modeling annual gas exchange trajectories, as a baseline for anticipating shifts with climate change. For example, a species' ability to maintain high winter photosynthesis (García-Plazaola et al. 1999, Ogaya and Peñuelas 2003, Gimeno et al. 2009) would benefit plant annual carbon balance as spring and summer droughts become more intense and frequent.

As indicators of physiological response of leaves and xylem to seasonal stress, we focused on stomatal conductance $\left(g_{s}\right)$, percent loss of stem xylem hydraulic conductivity (PLC) and photochemical efficiency of photosystem II $\left(F_{\mathrm{v}} / F_{\mathrm{m}}\right)$. We focused on the leaf and xylem hydraulic systems based on hypotheses for their correlated responses (Cavender-Bares et al. 2005). Several empirical and theoretical studies have shown that stomatal closure tracks loss of hydraulic function at multiple temporal scales (Sperry 2000, Meinzer et al. 2008, Johnson et al. 2011), diurnally during the growing season and seasonally during ongoing water stress. Hydraulic stress and freeze-thaw cycles can result in embolism of xylem conduits that impedes the transport of sap from the roots to the leaves (Pittermann 2010), reducing the capacity of stomata to remain open (Tognetti et al. 1998, Nardini and Salleo 2000, Peguero-Pina et al. 2011). We also focused on the photochemical efficiency of photosystem II, as a measure of photosynthetic function of leaves which is highly related to seasonal stress and may indicate acclimatization to extreme events (García-Plazaola et al. 1999).

To achieve our main goal we used two complementary approaches. First, we conducted a meta-analysis in summer versus winter for three woody plant functional types (winter deciduous angiosperms, evergreen angiosperms, and conifers) from ecosystems with and without summer drought across the temperate zone. Second, for critical detail on the response of species experiencing winter freezing in a drought prone ecosystem, and because the meta-analysis approach can be misleading due to pooling data for average patterns across species growing under disparate conditions and measured with varying techniques, we conducted a case study of Mediterranean species of the three functional types in central Spain.

We hypothesized that typical shifts in physiological performance from summer to winter would depend on whether the site experiences a strong summer drought, but also on the functional types (species varying in leaf habit and wood anatomy) and/or evolutionary lineages (i.e. angiosperms versus conifers), subject to local adaptation and/or phenotypic plasticity (Carnicer et al. 2013). In the absence of summer drought, we expected plants to have lower $g_{s}$ during winter than during summer (Morecroft and Roberts 1999, Ellsworth 2000, Miyazawa and Kikuzawa 2005) and to suffer winter declines in photochemical efficiency due to an inability to utilize or dissipate light energy at low temperatures (Martinez-Ferri et al. 2004, Demming-Adams et al. 2008), coinciding with a higher degree of embolism during freeze-thaw cycles (Sperry and Sullivan 1992, McCulloh et al. 2011). In contrast, species in systems that experience summer water stress, the stomatal closure, xylem embolism and loss of leaf photosynthetic function in summer might be equal to or even exceed those during winter (Tognetti et al. 1998, Gulías et al. 2009, Mahall et al. 2009, Prieto et al. 2009). We hypothesized that deciduous angiosperms, having wider xylem conduit diameters would show greater hydraulic vulnerability in both seasons than evergreen angiosperms and conifers, as reported in site-specific studies (Tyree and Cochard 1996, Cavender-Bares and Holbrook 2001). Additionally, as leaf phenology relates to hydraulic architecture (Wang et al. 1992) we expected evergreens to show a lower vulnerability to extreme cold temperatures than species with shorter leaf lifespan (deciduous angiosperms) which experience dormancy during winter (Cavender-Bares et al. 2005). We further tested whether extreme winter stress, as experienced in our case study site, would lead to further physiological declines from summer to winter, even in a drought-prone system, given that stem xylem embolism would accumulate, and the severe winter may drive severe declines in photochemical efficiency. Our data also allowed a test of the hypothesis that stomatal dynamics are influenced by the status of the hydraulic system generally across seasons. These hypotheses provided a baseline framework for understanding the impacts of seasonal extremes, and we provide a first test for different functional types across the temperate zone.

\section{Material and methods}

\section{Meta-analysis of summer versus winter function}

We compiled data for stomatal conductance $\left(g_{\mathrm{s}} ; \mathrm{mol} \mathrm{m}^{-2}\right.$ $\mathrm{s}^{-1}$ ), percent loss of hydraulic conductance (PLC), and dark acclimated photochemical efficiency of photosystem II $\left(F_{\mathrm{v}}\right)$ $\left.F_{\mathrm{m}}\right)$ from published papers, which included values for given species in summer and winter (Supplementary material Appendix 1 Table A1). These data are notably few in the literature, and extremely valuable, given the logistical challenges associated with collection of physiological data in extreme seasons. We searched exhaustively in the Web of Science (WOS, Thomson Reuters) and Google Scholar Web using multiple keywords. We only included data from papers that reported on measurements under natural conditions for a given species population for summer and winter months. If any manipulative treatment had been applied, only the values for untreated control plants were used, and when a given study contained seasonal data for multiple years these were averaged. For consistency, when data were available for different hours during the day for $g_{\mathrm{s}}$, only the data obtained from 10:00-12:00 were included. Our database includes a total of 210 points for species in given locations (92 for $g_{s}$, 46 for PLC and 72 for $F_{\mathrm{v}} / F_{\mathrm{m}}$ ) from 75 different studies of temperate sites around the world, with at least four species (and up to 37 species) per functional type (winter deciduous angiosperms, evergreen angiosperms, and conifers) in sites with and without summer drought for each variable (Supplementary material Appendix 1 Table A1). The term 'drought' is defined as a climatological drought, brought about when there is a prolonged period of relative soil water deficit, often associated with high temperatures. Sites without summer droughts were temperate forests with frequent and intense frosts. Sites defined by the authors to experience frequent summer droughts were mostly mediterranean climate-type sites. Half the 
drought-prone ecosystems also experienced winter frosts due to a continental influence (Supplementary material Appendix 1 Table A1).

Mean temperature $\left({ }^{\circ} \mathrm{C}\right)$ and relative humidity (\%) during summer and winter months were also compiled for each site using the values provided by the authors when available, and completing missing data with those recorded from the closest meteorological station. Using the climate data (mean temperature and relative humidity for summer and winter months) we calculated the vapour pressure deficit (VPD) at each site and season.

\section{Study site, local climate variables and species}

The study area was located in Alto Tajo Natural Park, central Spain (Guadalajara, Castilla-La Mancha). The climate is continental Mediterranean with hot and dry summers and very cold winters with frequent frosts (Supplementary Material Appendix 1 Fig. A2). Mean annual precipitation is $499 \mathrm{~mm}$ and mean annual temperature is $10.2^{\circ} \mathrm{C}$, with July the warmest month $\left(19.3^{\circ} \mathrm{C}\right)$ and February the coldest $\left(2.1^{\circ} \mathrm{C}\right)$ according to climatic data of the closest meteorological station (Molina de Aragón: $40^{\circ} 50^{\prime} 40^{\prime \prime} \mathrm{N}, 1^{\circ} 53^{\prime} 07^{\prime \prime} \mathrm{W}, 1063 \mathrm{~m}$ a.s.l., 1951-2007 period, data provided by the Spanish Agencia Estatal de Meteorología). The soils are poorly developed and formed mainly from Cretaceous and Jurassic limestone.

Local climatic data during the study period were obtained from a meteorological station installed in the study area. Variables included air temperature $\left({ }^{\circ} \mathrm{C}\right)$, soil water content $\left(\mathrm{m}^{3} \mathrm{~m}^{-3}\right)$, photosynthetically active radiation (PAR, $\mu \mathrm{mol}$ $\mathrm{m}^{-2} \mathrm{~s}^{-1}$ ) and vapor pressure deficit (VPD, $\mathrm{kPa}$ ). Longerterm averages for climatic variables were provided by the Spanish Agencia Estatal de Meteorología (AEMET) from a meteorological station located at $35 \mathrm{~km}$ from the sampling site (Molina de Aragón: 40 $50^{\prime} 40^{\prime \prime} \mathrm{N}, 1^{\circ} 53^{\prime} 07^{\prime \prime} \mathrm{W}$, $1063 \mathrm{~m}$ a.s.l., 1951-2007 period).

We selected four representative coexisting tree species: the winter deciduous oak Quercus faginea which has ringporous wood; the evergreen oak Quercus ilex subsp. ballota which has diffuse- to semi-ring porous wood; and the conifers Juniperus thurifera and Pinus nigra subsp. salzmannii. Within the study area, 3 to 12 adult trees per species were selected (see Fig. 2 for details on numbers of individuals sampled for each variable and species in each season). Mean diameter \pm SE at breast height (dbh) of the trees in the study area was $17.8 \pm 0.8 \mathrm{~cm}$ for $Q$. faginea, $15.1 \pm 0.6 \mathrm{~cm}$ for Q. ilex, $17.9 \pm 1.2 \mathrm{~cm}$ for $J$. thurifera and $28.7 \pm 1.2 \mathrm{~cm}$ for $P$. nigra, corresponding to mean ages of approximately 40-50 years. Measurements were made for 3-7 leaves (for $g_{\mathrm{s}}$ and $F_{\mathrm{v}} / F_{\mathrm{m}}$ ) or branches (PLC) per tree. Fully expanded and healthy looking branches and leaves were selected from the upper exposed part of the southern side of the crown.

\section{Physiological measurements}

Leaf physiological measurements were taken at a representative intermediate PAR, temperature and VPD (Supplementary material Appendix 1 Fig. A3). Leaf stomatal conductance to water vapour $\left(g_{s} ; \mathrm{mmol} \mathrm{m} \mathrm{m}^{-2} \mathrm{~s}^{-1}\right)$ was measured on fully expanded leaves in summer (July) of 2009 and in winter (February) of 2010. Measurements were conducted using a steady-state diffusion leaf porometer between 10:00-12:00 under ambient conditions.

For measurements of hydraulic conductivity (Sperry and Tyree 1988, Melcher et al. 2012), current year shoots were collected at midday from the most exposed part of the crown. For conifers, stem segments $10-15 \mathrm{~cm}$ in length were cut under water, wrapped in moist paper towels, placed in sealable plastic bags which had been previously exhaled in, within a dark plastic bag filled with wet paper towels and brought to the laboratory. For the two oak species, given their longer vessels, shoots were cut off the trees under water to prevent cavitation and placed in small water bottles filled to the top and transported horizontally to the laboratory. Hydraulic conductance was determined using the XYL'EM apparatus, based on a high-resolution liquid mass flowmeter. Stem segments of $2-3 \mathrm{~cm}$ in length for conifers and $4.5-5.5 \mathrm{~cm}$ in length for oaks, all with diameters $<5$ $\mathrm{mm}$ were recut under pure water, and bark and phloem were removed at the ends.

Samples were freshly cut with a scalpel at both ends and connected to the system by silicone tubing sealed with cable ties to prevent leakage. The stem segments were placed under water with the bath temperatures recorded using the XYL'EM software which corrected for the effect of temperature on the viscosity of water by standardizing hydraulic conductance to $20^{\circ} \mathrm{C}$. Degassed $10 \mathrm{mmol} \mathrm{KCl}$ in ultrapure water was used as the flow solution. Initial stem xylem hydraulic conductance was obtained as the ratio of the flow rate through the samples once it had stabilized, typically after 5-10 min, at the known flow solution delivery pressure of $0.02 \mathrm{MPa}$, chosen to avoid flushing naturally formed emboli from the stem segments. Stems were then flushed at an applied pressure of $0.1 \mathrm{MPa}$ for $2 \mathrm{~min}$, which preliminary tests showed was sufficient to flush out all emboli; longer flushes or higher pressures did not increase the flow rate further. Stems were measured again under low pressure $(0.02 \mathrm{MPa})$ until a stable state flow rate was achieved to determine the maximum stem xylem hydraulic conductance. The percent loss of conductivity (PLC) was calculated as the relationship between initial and maximum hydraulic conductivity when emboli were removed (in \%). All tubing, containers and manifolds used were bleached every week with a $10 \%$ bleach solution.

The use of small segments for Quercus was based on that of previous comparative studies (Cavender-Bares and Holbrook 2001), such that segment lengths were smaller than the median xylem conduit length. This approach would not allow determination of maximum stem hydraulic conductivity, but allows calculation of PLC (Melcher et al. 2012), and, importantly, allowed us to minimize flushing time, to avoid plugging that could occur during the flushing, which would have been likely if extremely long stem segments were used. The danger of removing emboli by flushing, and arriving at artificially low PLC values was minimized by the careful handling of stem segments described above, and confirmed by the high PLC values for these species. Additionally, in the case of Quercus, we ensured the stem segments used were from the current year growth, as old growth segments could contain non-functional air filled xylem conduits. 
Photochemical efficiency of photosystem II (maximum PSII quantum yield; $F_{\mathrm{v}} / F_{\mathrm{m}}$ ) was measured with a fluorometer, during summer (July) of 2009 and winter (February) of 2010. Chlorophyll fluorescence was evaluated under ambient $\mathrm{CO}_{2}$ concentration in 30 min-dark-adapted leaves $\left(F_{\mathrm{v}} / F_{\mathrm{m}}\right.$ values under these conditions were highly and significantly correlated with $F_{\mathrm{v}} / F_{\mathrm{m}}$ at predawn as shown by a pilot study). $F_{\mathrm{v}} / F_{\mathrm{m}}$ is the ratio of variable $\left(F_{\mathrm{v}}\right)$ to maximum $\left(F_{\mathrm{m}}\right)$ fluorescence: $F_{\mathrm{v}} / F_{\mathrm{m}}=\left(F_{\mathrm{m}}-F_{0}\right) / F_{\mathrm{m}}$, where $F_{0}$ is the minimum fluorescence. $F_{\mathrm{v}} / F_{\mathrm{m}}$ is an index of plant physiological status that reflects photoinhibitory damage in response to extreme temperatures, excess light and/or water stress (Valladares and Pearcy 1997, Maxwell and Johnson 2000). Thus, low values of $F_{\mathrm{v}} / F_{\mathrm{m}}$ indicate a reduction in photosynthetic capacity (Farquhar and Sharkey 1982).

\section{Statistical analyses}

For the meta-analysis, we tested for differences in $g_{s}$, percent loss of hydraulic conductivity (PLC) and declines in dark acclimated photochemical efficiency $\left(F_{\mathrm{v}} / F_{\mathrm{m}}\right)$ as a function of season and functional type, and for their interaction, using analyses of variance (ANOVA), for sites with and without summer drought. Further, we determined differences among functional types and seasons using one-way ANOVAs. We also conducted analyses of the covariance (ANCOVA) using each physiological variable as a function of monthly temperature for the given seasons and functional types and as a function of vapour pressure deficit in separate analyses. Linear regressions were calculated between seasonal physiological variables, temperature and VPD using the meta-analysis data. Measurements taken at our study site were analyzed in the same way for the differences in $g_{\mathrm{s}}$, PLC and $F_{\mathrm{v}} / F_{\mathrm{m}}$ between species and summer versus winter. Prior to analyses, replicate measurements were averaged for each individual. Normality was tested with a Shapiro test and non-normal variables were transformed (Zar 1999). If after transformation normality had not been achieved, non-parametric statistics (KruskalWallis or Wilcoxon test) were used (Zar 1999). Analyses were implemented using (<www.R-project.org $>$ ).

\section{Results}

\section{Findings from the meta-analysis: general framework for summer-winter variation in climate and ecophysiology of three functional types}

Seasonal climatic variables differed between sites with and without summer droughts (mean temperature, $\mathrm{F}=11.1$, $\mathrm{p}=0.001 ;$ mean VPD, $\mathrm{F}=25.6, \mathrm{p}<0.0001)$. At sites without summer droughts, mean seasonal temperatures and vapor pressure deficits were lower $\left(20.6 \pm 0.1^{\circ} \mathrm{C}\right.$ and $2 \pm 1.2^{\circ} \mathrm{C}$ mean summer and winter temperatures and mean VPD of $1.2 \pm 0.006 \mathrm{kPa}$ and $0.4 \pm 0.06 \mathrm{kPa}$ for summer and winter, respectively), than for sites with summer droughts $\left(23.5 \pm 0.08^{\circ} \mathrm{C}\right.$ and $7.7 \pm 0.3^{\circ} \mathrm{C}$ mean summer and winter temperatures and mean VPD of $1.8 \pm 0.01$ and $0.6 \pm 0.008 \mathrm{kPa}$ for summer and winter, respectively).

The relative magnitude of $g_{s}$ for woody species in winter versus summer depended on whether a summer drought was experienced in its system (Table 1, Fig. 1). In systems without summer droughts, trees and shrubs showed substantially lower $g_{s}$ during winter compared to summer (Table 2, Fig. 1a). By contrast, in drought-prone systems all species maintained or increased $g_{s}$ during winter, with the exception of the leafless winter deciduous trees. Species in these systems with higher temperatures in the summer had on average lower $g_{s}$ than species in cooler systems without climatic drought, especially for conifers and deciduous angiosperms (Table 2, Fig. 1b). Indeed, functional types differed in $g_{s}$, experiencing the deciduous angiosperms the highest $g_{s}$ values during summer at sites without droughts, and the conifers experiencing the lowest $g_{\text {s }}$ during summer at sites with droughts (Table 2, Fig. 1a-b).

PLC also shifted seasonally (Table 2), increasing during winter for all functional types and ecosystems (Fig. 1c-d). The functional types differed in the degree by which PLC increased during winter, with deciduous angiosperms showing the strongest increase corresponding to their leafless winter season (Fig. 1c-d). The evergreen angiosperms increased in PLC during winter, significantly at sites without summer droughts. Conifers had lower PLC than angiosperms across all systems and seasons (Table 2, Fig. 1c-d).

In addition, there were substantial seasonal shifts in $F_{\mathrm{v}} / F_{\mathrm{m}}$ (Table 2). Species of all functional types decreased their photochemical efficiency during winter at sites without summer drought, especially the conifer species (Fig. 1e). At sites with summer drought, the evergreen angiosperms and the coniferous species did not show significant seasonal differences in $F_{\mathrm{v}} / F_{\mathrm{m}}$ (Fig. 1f).

Results from the analyses of the covariance (ANCOVA, Supplementary material Appendix 1 Table A2, A3) substituting season (summer and winter) for seasonal temperatures or VPD indicated that both climatic variables had a significant effect on all physiological variables $\left(g_{s}\right.$, PLC and $\left.F_{\mathrm{v}} / F_{\mathrm{m}}\right)$, with the exception of the response of $g_{s}$ to VPD at sites with summer drought. These results highlight that the seasonal shifts found are related to the differences of summer and winter temperature and VPD, which are highly correlated (Supplementary material Appendix 1 Table A2, A3, Fig. A1).

\section{Case study in a drought-prone ecosystem: climatic variation and ecophysiological differences in summer versus winter of coexisting species}

The ecosystem in our case study experienced strong seasonal temperature variations (Supplementary material Appendix 1 Fig. A2, A3). The summer of 2009 had similar mean temperature to summer means for the 1951-2007 period, but was particularly dry, with only $33 \mathrm{~mm}$ of precipitation in the three summer months. The winter of 2010 was wet and had extremely low temperatures, reaching a minimum mean daily temperature of $-14^{\circ} \mathrm{C}$ (Supplementary material Appendix 1 Fig. A3).

The study species showed strong shifts in physiology between summer and winter (Fig. 2). Differences in $g_{\text {s }}$ were found among species $(\mathrm{F}=10.7, \mathrm{p}<0.0001$; ANOVA), and between summer and winter $(\mathrm{F}=97.8, \mathrm{p}<0.0001)$, with a significant interaction between species and season $(\mathrm{F}=8.9 ; \mathrm{p}<0.0001)$. Both Quercus species had high $g_{s}$ 
Table 1. Summary of overall findings for the meta-analysis of global data for temperate forests without and with summer drought, and from a case-study in a Mediterranean forest. Characteristic differences in stomatal conductance $\left(g_{s}\right)$, percent loss of stem hydraulic conductivity (PLC) and photochemical efficiency of photosystem II $\left(F_{v} / F_{m}\right)$ between summer and winter are indicated by a $(+)$ for higher, $(-)$ for lower and by a $(\sim)$ for similar.

\begin{tabular}{|c|c|c|c|c|c|c|}
\hline & & & Meta-analysis of globa & d data & & \\
\hline & $\begin{array}{r}\text { No sun } \\
\text { drou }\end{array}$ & $\begin{array}{l}\text { mmer } \\
\text { ight }\end{array}$ & With sumn & ner drought & Case study in Mec & diterranean system \\
\hline & summer & winter & summer & winter & summer & winter \\
\hline$g_{\mathrm{s}}$ & + & - & $\sim$ or - & $\sim$ or + & + & - \\
\hline PLC & - & + & $\sim$ (evergreen angiosperm) or - & $\sim$ (evergreen angiosperm) or + & $-($ except + for $Q$. ilex $)$ & $+($ except - for $Q$. ilex $)$ \\
\hline$F_{v} / F_{m}$ & + & - & $\sim$ & $\sim$ & + & - \\
\hline
\end{tabular}
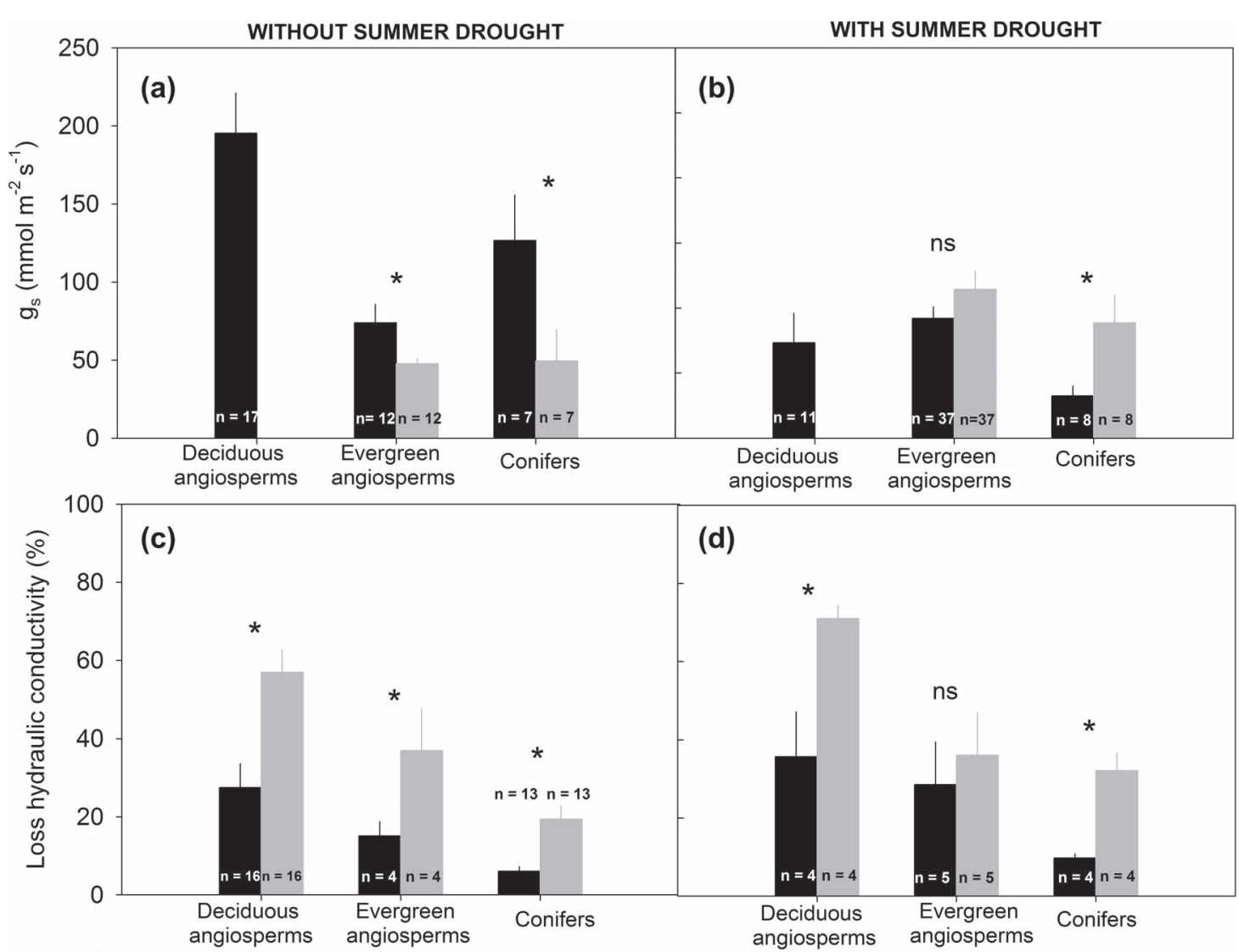

(d)

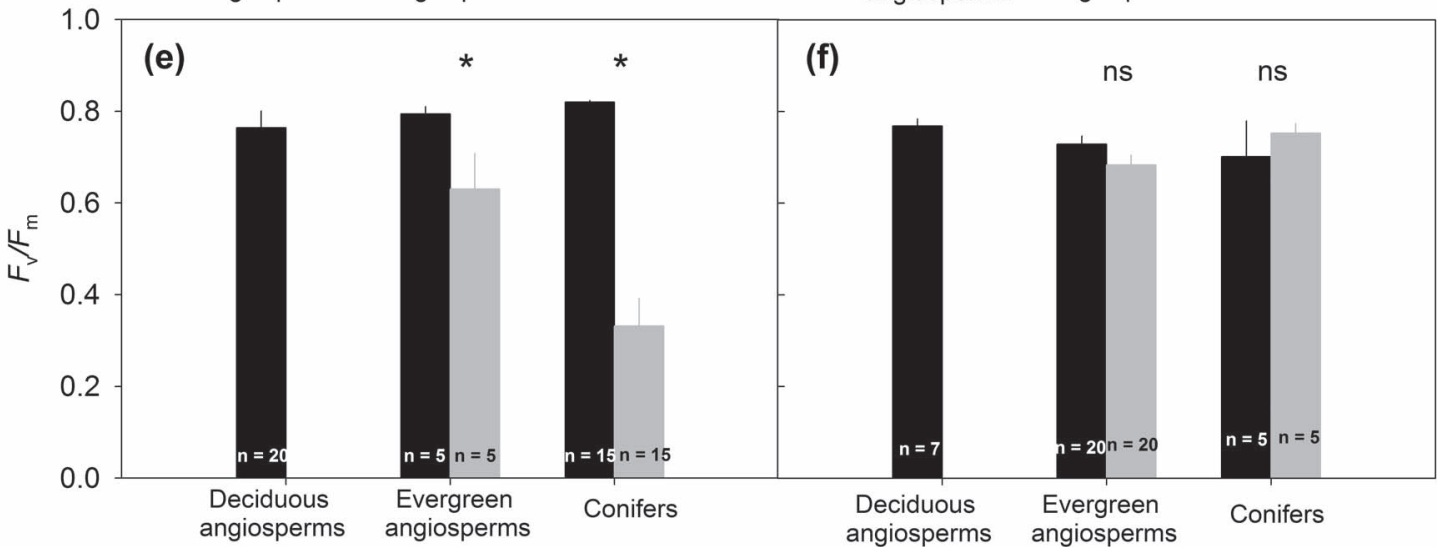

Figure 1. Results of a meta-analysis of shifts in leaf and stem physiology between summer and winter for woody species across the temperate zone, including mean values $( \pm \mathrm{SE})$ for $(\mathrm{a}, \mathrm{b})$ stomatal conductance $\left(g_{\mathrm{s}}, \mathrm{mmol} \mathrm{m}^{-2} \mathrm{~s}^{-1}\right)$, (c, d) percent loss of hydraulic conductivity (PLC) and (e, f) photochemical efficiency of photosystem II $\left(F_{\mathrm{v}} / F_{\mathrm{m}}\right)$ during summer (black bars) and winter (grey bars) for deciduous angiosperms, evergreen angiosperms and conifers at sites without summer drought (a, c, e) and with summer drought $(b, d, f)$. Asterisks $(*)$ indicate significant differences $(p<0.05)$ between summer and winter within each functional type. The number of species used for each functional type (n) is indicated at the base of each bar. 
Table 2. Results from the analyses of variance (ANOVA) for stomatal conductance $\left(g_{\mathrm{s}}\right)$, percent loss of hydraulic conductivity (PLC) and photochemical efficiency of photosystem II $\left(F_{\mathrm{v}} / F_{\mathrm{m}}\right)$ at sites without summer drought and with summer drought. Explanatory variables included season (S: summer versus winter) and functional type of temperate woody species (FT: deciduous angiosperm, evergreen angiosperm and conifer) and the interaction among them. The adjusted $R^{2}$ value and significance of the model ( $p$-value) are indicated for each model.

\begin{tabular}{|c|c|c|c|c|c|c|}
\hline & & DF & Sum Sq & Mean Sq & F-value & $\mathrm{p}$-value \\
\hline \multicolumn{7}{|l|}{$g_{\mathrm{s}}$} \\
\hline Without summer drought & $\mathrm{S}$ & 1 & 1083.45 & 1083.45 & 137.78 & $<0.0001$ \\
\hline \multirow[t]{2}{*}{$\mathrm{R}^{2}=0.74 ; \mathrm{p}<0.0001$} & FT & 2 & 27.90 & 13.90 & 1.77 & 0.18 \\
\hline & $\mathrm{S} \times \mathrm{FT}$ & 2 & 545.10 & 272.60 & 34.66 & $<0.0001$ \\
\hline With summer drought & $\mathrm{S}$ & 1 & 4.26 & 4.26 & 0.37 & 0.54 \\
\hline \multirow[t]{2}{*}{$\mathrm{R}^{2}=0.41 ; p<0.0001$} & FT & 2 & 550.40 & 275.20 & 23.97 & $<0.0001$ \\
\hline & $\mathrm{S} \times \mathrm{FT}$ & 2 & 399.10 & 199.60 & 17.38 & $<0.0001$ \\
\hline \multicolumn{7}{|l|}{ PLC } \\
\hline Without summer drought & $\mathrm{S}$ & 1 & 90.39 & 90.39 & 30.04 & $<0.0001$ \\
\hline \multirow[t]{2}{*}{$\mathrm{R}^{2}=0.49 ; \mathrm{p}<0.0001$} & FT & 2 & 108.60 & 54.32 & 18.04 & $<0.0001$ \\
\hline & $\mathrm{S} \times \mathrm{FT}$ & 2 & 2.90 & 1.43 & 0.47 & 0.63 \\
\hline With summer drought & $\mathrm{S}$ & 1 & 22.59 & 22.59 & 9.52 & $<0.001$ \\
\hline \multirow[t]{2}{*}{$\mathrm{R}^{2}=0.44 ; p=0.004$} & FT & 2 & 30.40 & 15.20 & 6.41 & $<0.001$ \\
\hline & $\mathrm{S} \times \mathrm{FT}$ & 2 & 5.55 & 2.77 & 1.17 & 0.33 \\
\hline \multicolumn{7}{|l|}{$F_{\mathrm{v}} / F_{\mathrm{m}}$} \\
\hline Without summer drought & $\mathrm{S}$ & 1 & 6.73 & 6.73 & 529.18 & $<0.001$ \\
\hline \multirow[t]{2}{*}{$\mathrm{R}^{2}=0.91 ; p<0.0001$} & FT & 2 & 2.17 & 1.08 & 85.20 & $<0.001$ \\
\hline & $\mathrm{S} \times \mathrm{FT}$ & 2 & 1.73 & 0.87 & 68.00 & $<0.001$ \\
\hline With summer drought & $\mathrm{S}$ & 1 & 0.86 & 0.86 & 61.30 & $<0.0001$ \\
\hline \multirow[t]{2}{*}{$R^{2}=0.83 ; p<0.0001$} & FT & 2 & 1.63 & 0.81 & 58.03 & $<0.0001$ \\
\hline & $\mathrm{S} \times \mathrm{FT}$ & 2 & 1.89 & 0.94 & 67.28 & $<0.0001$ \\
\hline
\end{tabular}

during summer, whereas the conifers had very low values during both summer and winter (below $50 \mathrm{mmol} \mathrm{m}^{-2} \mathrm{~s}^{-1}$ ). The evergreen Quercus ilex declined significantly in $g_{s}$ during the winter, reaching levels similar to the conifers (Fig. 2a).

The species also differed strongly in their dynamics of PLC $\left(\chi^{2}=38.62, p<0.0001\right.$; Kruskal-Wallis test $)$. Deciduous Quercus faginea showed especially strong xylem cavitation, with PLC values of $80 \%$ during summer, and further increasing to $90 \%$ during winter (Fig. 2b). By contrast, the PLC for the evergreen $Q$. ilex was $\approx 55 \%$ during summer, and decreased during winter to approximately $45 \%$. Both conifers showed high resistance to stem cavitation, with PLC values $\approx 0 \%$ during summer that increased only to 3 and $9 \%$ during winter for $J$. thurifera and P. nigra, respectively (Fig. 2b).

During summer, $F_{\mathrm{v}} / F_{\mathrm{m}}$ values for all species ranged 0.83-0.86 indicating normal leaf functioning (Schreiber et al. 1994). However, these values significantly declined in all study species during winter (to 0.54 for the evergreen Quercus and to $\approx 0.65$ for the conifers), indicating important loss of photosynthetic function ( $\mathrm{W}=208, \mathrm{p}<0.0001$; Wilcoxon test) (Fig. 2c).

\section{Discussion}

The data supported a general framework for seasonal variation in physiological performance of trees across the temperate zone. Differences were found among functional types and for species in ecosystems with and without summer drought. Ecosystems without summer droughts tended to have mild summers and cold winters, and thus it is not surprising that all functional types declined in $g_{s}$ during the winter, coinciding with an increased PLC and reduced
$F_{\mathrm{v}} / F_{\mathrm{m}}$. Consistent with mechanistic studies of individual woody temperate species (Salleo et al. 2000, Cochard et al. 2002, Pratt et al. 2005) these results indicate an efficient stomatal control to avoid catastrophic embolism and desiccation of leaf tissues when winter cold results in a decreased water supply to the canopy.

By contrast, drought-prone ecosystems experienced warmer summers coupled with higher VPD and milder winters. As expected, most species showed low $g_{s}$ during the summer, likely a response to avoid desiccation (Chaves 1991, Escalona et al. 1999). It is possible that both chemical and hydraulic signals interact to control stomatal behavior under water stress (Salleo et al. 2000, Comstock 2002, Martínez-Vilalta et al. 2002, Lo Gullo et al. 2003). However, the results from drought-prone ecosystems indicated that reductions in $g_{s}$ were not coupled with increases in stem PLC, suggesting that the stomatal closure may be regulated by chemical signals and/or by leaf and/or root hydraulic vulnerability (Whitehead 1998, Bucci et al. 2013). Moreover, during the winter PLC increased while stomata remained open, or even opened further. Such a finding might reflect a strong redundancy in the stem hydraulic system for these species, such that plant hydraulic conductance would not be strongly impacted by a considerable reduction in functional conduit number (Zimmermann 1983, Lo Gullo et al. 2003). More difficult to explain is why PLC increased from summer to winter at sites in which winter temperature is usually mild. We suggest that tree species growing in drought-prone ecosystems are more adapted to drought-induced embolism (Kolb and Sperry 1999, Willson and Jackson 2006), but are still prone to freeze-thaw induced embolism. In fact, a single freezing event has been shown to embolize most conduits in a number of angiosperm and conifer species, especially when 


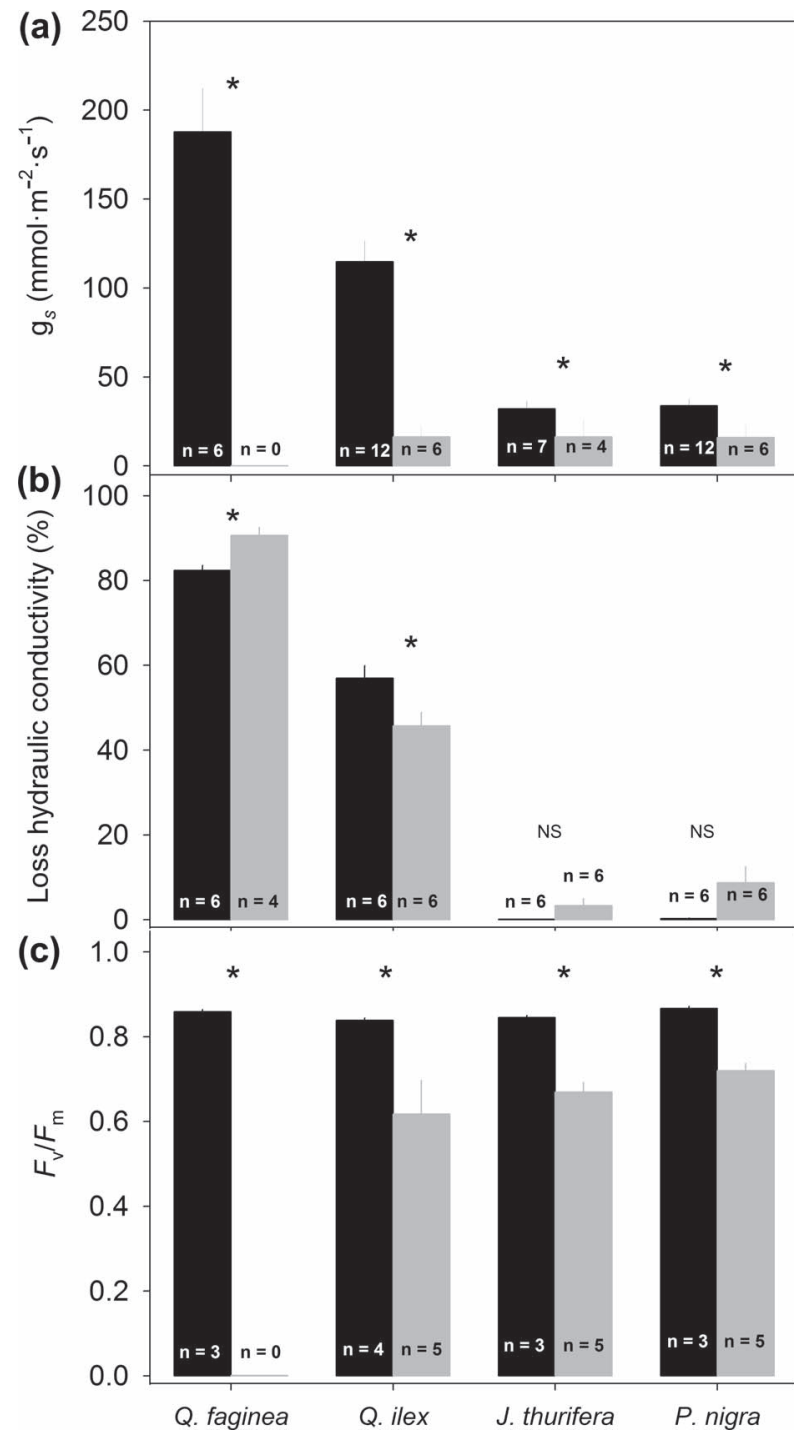

Figure 2. Shifts in leaf and stem physiology between summer and winter for four common, coexisting species in central Spain, including mean values $( \pm S E)$ for (a) stomatal conductance $\left(g, \mathrm{mmol} \mathrm{m}^{-2} \mathrm{~s}^{-1}\right)$, (b) percent loss of hydraulic conductivity (PLC) and (c) photochemical efficiency of photosystem II $\left(F_{\mathrm{v}} / F_{\mathrm{m}}\right)$ for the study species - Quercus faginea (winter deciduous angiosperm), Quercus ilex (evergreen angiosperm), Juniperus thurifera and Pinus nigra (conifers) - during summer (black bars) and winter (grey bars). Asterisks $(*)$ indicate significant differences $(p<0.05)$ between summer and winter within each species. The number of individuals per measurement $(\mathrm{n})$ is indicated at the bottom of each bar.

preceded by drought stress (Cochard and Tyree 1990, Cochard et al. 1997, Willson and Jackson 2006, Charrier et al. 2013). Another possibility is that a faster thawing rate in drought-prone ecosystems, due to high daily temperature oscillations, increases the probability of xylem embolism because less time is available for bubbles to re-dissolve in the xylem sap (Sperry 1995, Langan et al. 1997, Feild and Brodribb 2001).

A further novel finding of our meta-analysis was the differences in the seasonal dynamics of $F_{\mathrm{v}} / F_{\mathrm{m}}$ between ecosystem types. While species of ecosystems without summer drought showed depressed $F_{\mathrm{v}} / F_{\mathrm{m}}$ in the winter, consistent with cold damage of the components of the photosynthetic apparatus (Adams III et al. 1994) the $F_{\mathrm{v}} / F_{\mathrm{m}}$ remained high in winter at drought-prone ecosystems. Such a high winter $F_{\mathrm{v}} / F_{\mathrm{m}}$ could be enabled by strong photo-protection during the summer (García-Plazaola et al. 2008) further maintained into the winter, or due to the accumulation of pigments during the onset of winter stress (i.e. cold temperatures and bright sunlight conditions) to alleviate excessive energy and photoinhibition and to provide antioxidant protection (Ruelland et al. 2009, Hughes 2011). These findings emphasize the strong variation in the photosynthetic integrity among species subjected to different stress during winter (Adams III et al. 1994).

Our case study in an ecosystem subjected to frequent summer droughts and winter freeze-thaw events showed a pattern more typical of that for systems without summer droughts. This finding is likely due to the fact that winters are particularly harsh in our study system compared to those typical of other drought-prone ecosystems, only half of which experienced freeze-thaw events. The pronounced $g_{s}$ and $F_{\mathrm{v}} / F_{\mathrm{m}}$ declines during winter of our evergreen Mediterranean species (i.e. Quercus ilex, Pinus nigra and Juniperus thurifera) indicate physiological limitations as a result freezing cycles, and strong sensitivity to low temperatures (Martinez-Ferri et al. 2004).

\section{Physiological performance of contrasting functional types under stress}

Our results suggest that the responses of particular functional types might confer an advantageous performance in a changing climate (Carnicer et al. 2013). Evergreen species in drought-prone systems showed similar or higher $g_{s}$ in winter relative to summer, indicating a potential to conduct photosynthesis during winter when temperatures climb during the day. In some cases the reported winter $g_{\mathrm{s}}$ values were quite high (White et al. 2000, Flexas et al. 2001, Ogaya and Peñuelas 2003, Maseyk et al. 2008, Peters et al. 2008, Gimeno et al. 2012). A capacity to maintain carbon gain during winter might be particularly important for annual carbon balance in species that experience strong functional declines during summer drought. Therefore, evergreen species may show a competitive advantage over deciduous plants (Gimeno et al. 2009, Choat et al. 2011), especially if summer droughts become even more extreme with climate change. Despite this general pattern, it is worth noting that species belonging to particular functional types may be functionally distinct when subjected to different stresses due to local adaptation or phenotypic plasticity (Reich et al. 2003).

The meta-analysis and case study showed higher summer and winter PLC for angiosperms, and particularly for deciduous species, than for conifers. These results extend previous reports of tradeoffs between xylem anatomy, hydraulic capacity and leaf gas exchange (Sperry et al. 1994, Feild and Brodribb 2001, Choat et al. 2011). The differences we found among functional types in PLC are likely related to variation in the xylem conduit diameters, as larger conduits tend to be more prone to drought and especially to freeze-thaw induced embolism (Sperry et al. 1994, Feild and Brodribb 2001, Choat et al. 2011). Within angiosperms, 
evergreen species usually have smaller vessel diameters with diffuse porous anatomy in contrast to deciduous species with large diameter earlywood vessels and ring porous anatomy (Cavender-Bares et al. 2005). Indeed, the PLC values in our case study species were strongly positively correlated with xylem maximum conduit diameter compiled from published data $\left(R^{2}=0.98\right.$, Supplementary material Appendix 1 Table A4). Narrow xylem conduits are thus adaptive for avoiding freeze-thaw induced embolism (Carnicer et al. 2013, Charrier et al. 2013). Wider conduits enable larger air bubbles to form and/or persist than narrow conduits, as in larger conduits bubbles would take more time to re-dissolve before the onset of a critical tension would cause them to expand (Tyree and Sperry 1989, Tyree and Cochard 1996). By contrast with freeze-thaw embolism, water-stress driven embolism depends less on conduit size than on the permeability and air-seeding vulnerability of interconduit pit membranes (Sperry and Sullivan 1992).

While most species increased PLC in winter, some declined or maintained PLC in winter relative to summer (Sperry 1993, Magnani and Borghetti 1995, Tognetti et al. 1998, Nardini et al. 2000, Cavender-Bares et al. 2005). These results suggest that seasonal resistance to extreme events might be conditioned by contrasting trait syndromes (Carnicer et al. 2013), such as the capacity to experience a bimodal xylogenesis (Camarero et al. 2010) or to refill the conduits (Nardini et al. 2011, 2014). For example, Q. ilex in our case study, which showed reduced PLC in winter compared to summer, could have formed additional xylem during fall, allowing the recovery of the hydraulic function after drought-induced embolism or may have avoided extensive embolism by refilling its conduits. The mechanisms of refilling are still under debate (Nardini et al. 2014), but are likely related to carbohydrate dynamics (Ewers et al. 2001, Améglio et al. 2002, Charrier et al. 2013), i.e. involving the conversion of starch to soluble sugars that allow refilling through positive pressures in the xylem. Instead, other functional types (e.g. the deciduous angiosperms, Q. faginea) tolerate winter embolism until new xylem is formed during the growing season (Améglio et al. 2002), likely providing a functional disadvantage during the winter and early spring (Wang et al. 1992).

\section{Conclusions and limitations of the study}

This study is the first to our knowledge to investigate the general pattern of summer to winter transitions for woody species across the temperate zone. The meta-analysis supported an overall framework for the differences in physiological performance between summer and winter across the temperate zone. However, this approach is subject to a number of uncertainties. First, species were pooled across studies varying in methodology. Second, this approach cannot directly indicate the factors driving the physiological dynamics. For instance, the differences found at the functional type level could also be the result of different species present in each forest type. Our results pointed to several strong conclusions. First, winter is an equal or even stronger stress than summer across the temperate zone, including for Mediterranean vegetation. The differences among functional types in seasonal dynamics of physiological performance are strong enough to suggest their importance in determining ecosystem productivity throughout the year, especially in systems for which carbon gain is limited to a few months. The patterns shown here present a baseline against which to compare shifts for given species and vegetation systems with ongoing climate change.

Acknowledgements - The authors thank the Junta de CastillaLa Mancha, Director and Park rangers of the Alto Tajo Natural Park for the permission and facilities provided. Meteorological data was provided by the Spanish Agencia Estatal de Meteorología. We are very grateful to A. Forner and A. Lázaro for their valuable assistance with climatic data processing and logistics in the field, respectively. This research was supported by the Spanish Ministry of Economy and Competitiveness with the grants FPI (CGL200766066-C04-02), Consolider Montes (CSD2008 00040) and VULGLO (CGL2010 22180 C03 03), and by the Community of Madrid grant REMEDINAL 2 (CM S2009 AMB 1783) and National Science Foundation Grant no. 0546784. This study was conceived and performed within the Globimed network (<www.globimed.net $>$ ).

\section{References}

Adams III, W. W. et al. 1994. 'Photoinhibition' during winter stress: involvement of sustained xanthophyll cycle-dependent energy dissipation. - Aust. J. Plant Physiol. 22: 261-276.

Améglio, T. et al. 2002. Winter embolism, mechanisms of xylem hydraulic conductivity recovery and springtime growth patterns in walnut and peach trees. - Tree Physiol. 22: 1211-1220.

Bucci, S. J. et al. 2013. The stem xylem of Patagonian shrubs operates far from the point of catastrophic dysfunction and is additionally protected from drought-induced embolism by leaves and roots. - Plant Cell Environ. 36: 2163-2174.

Camarero, J. J. et al. 2010. Plastic bimodal xylogenesis in conifers from continental Mediterranean climates. - New Phytol. 185: 471-480.

Carnicer, J. et al. 2013. Contrasting trait syndromes in angiosperms and conifers are associated with different responses of tree growth to temperature on a large scale. - Front. Plant Sci. 4: 409 .

Cavender-Bares, J. and Holbrook, N. M. 2001. Hydraulic properties and freezing-induced cavitation in sympatric evergreen and deciduous oaks with contrasting habitats. - Plant Cell Environ. 24: 1243-1256.

Cavender-Bares, J. et al. 2005. Summer and winter sensitivity of leaves and xylem to minimum freezing temperatures: a comparison of co-occurring Mediterranean oaks that differ in leaf lifespan. - New Phytol. 168: 597-612.

Charrier, G. et al. 2013. Evaluation of the impact of frost resistances on potential altitudinal limit of trees. - Tree Physiol. 33: 891-902.

Chaves, M. M. 1991. Effects of water deficits on carbon assimilation. - J. Exp. Bot. 42: 1-16.

Cherubini, P. et al. 2003. Identification, measurement and interpretation of tree rings in woody species from mediterranean climates. Biol. Rev. Camb Phil. Soc. 78: 119-148.

Choat, B. et al. 2011. Xylem traits mediate a tradeoff between resistance to freeze-thaw-induced embolism and photosynthetic capacity in overwintering evergreens. - New Phytol. 191: 996-1005.

Cochard, H. and Tyree, M. T. 1990. Xylem dysfunction in Quercus - vessel sizes, tyloses, cavitation and seasonal-changes in embolism. - Tree Physiol. 6: 393-407.

Cochard, H. et al. 1997. Developmental control of xylem hydraulic resistances and vulnerability to embolism in Fraxinus 
excelsior L: impacts on water relations. - J. Exp. Bot. 48: 655-663.

Cochard, H. et al. 2002. Unraveling the effects of plant hydraulics on stomatal closure during water stress in walnut. - Plant Physiol. 128: 282-290.

Comstock, J. P. 2002. Hydraulic and chemical signalling in the control of stomatal conductance and transpiration. - J. Exp. Bot. 53: 195-200.

Demming-Adams, B. et al. 2008. Characteristics and speciesdependent employment of flexible versus sustained thermal dissipation and photoinhibition. - In: Demming-Adams, B. et al. (eds), Photoprotection, photoinhibition, gene regulation and environment. Advances in photosynthesis and respiration. Springer.

Ellsworth, D. S. 2000. Seasonal $\mathrm{CO}_{2}$ assimilation and stomatal limitations in a Pinus taeda canopy. - Tree Physiol. 20: 435-445.

Escalona, J. M. et al. 1999. Stomatal and non-stomatal limitations of photosynthesis under water stress in field-grown grapevines. - Aust. J. Plant Physiol. 26: 421-433.

Ewers, F. W. et al. 2001. Seasonal variation in xylem pressure of walnut trees: root and stem pressures. - Tree Physiol. 21: 1123-1132.

Farquhar, G. D. and Sharkey, T. D. 1982. Stomatal conductance and photosynthesis. - Annu. Rev. Plant Physiol. 33: 317-345.

Feild, T. S. and Brodribb, T. 2001. Stem water transport and freeze-thaw xylem embolism in conifers and angiosperms in a Tasmanian treeline heath. - Oecologia 127: 314-320.

Flexas, J. et al. 2001. Seasonal patterns and control of gas exchange in local populations of the Mediterranean evergreen shrub Pistacia lentiscus L. - Acta Oecol. 22: 33-43.

García-Plazaola, J. I. et al. 1999. Diurnal changes in antioxidant and carotenoid composition in the Mediterranean schlerophyll tree Quercus ilex (L) during winter. - Plant Sci. 143: $125-133$.

García-Plazaola, J. I. et al. 2008. Photoprotective responses of Mediterranean and Atlantic trees to the extreme heat-wave of summer 2003 in southwestern Europe. - Trees-Str. Funct. 22: 385-392.

Gimeno, T. E. et al. 2009. Plasticity and stress tolerance override local adaptation in the responses of Mediterranean holm oak seedlings to drought and cold. - Tree Physiol. 29: 87-98.

Gimeno, T. E. et al. 2012. Enhanced growth of Juniperus thurifera under a warmer climate is explained by a positive carbon gain under cold and drought. - Tree Physiol. 32: 326-336.

Granda, E. et al. 2013. Intensity and timing of warming and drought differentially affect growth patterns of co-occurring Mediterranean tree species. - Eur. J. For. Res. 132: 469-480.

Gulías, J. et al. 2009. Seasonal and inter-annual variations of gas exchange in thirteen woody species along a climatic gradient in the Mediterranean island of Mallorca. - Flora 204: 169-181.

Hiyama, T. et al. 2005. Seasonal variation in stomatal conductance and physiological factors observed in a secondary warm-temperate forest. - Ecol. Res. 20: 333-346.

Hughes, N. M. 2011. Winter leaf reddening in 'evergreen' species. - New Phytol. 190: 573-581.

Johnson, D. M. et al. 2011. Hydraulic patterns and safety margins, from stem to stomata, in three eastern US tree species. - Tree Physiol. 31: 659-668.

Karavatas, S. and Manetas, Y. 1999. Seasonal patterns of photosystem II photochemical efficiency in evergreen sclerophylls and drought semi-deciduous shrubs under Mediterranean field conditions. - Photosynthetica 36: 41-49.

Kolb, K. J. and Sperry, J. S. 1999. Differences in drought adaptation between subspecies of sagebrush (Artemisia tridentata). - Ecology 80: 2373-2384.
Langan, S. J. et al. 1997. Xylem dysfunction caused by water stress and freezing in two species of co-occurring chaparral shrubs. - Plant Cell Environ. 20: 425-437.

Lo Gullo, M. A. et al. 2003. Drought resistance of 2-year-old saplings of Mediterranean forest trees in the field: relations between water relations, hydraulics and productivity. - Plant Soil 250: 259-272.

Lo Gullo, M. A. et al. 2005. Diurnal and seasonal variations in leaf hydraulic conductance in evergreen and deciduous trees. - Tree Physiol. 25: 505-512.

Magnani, F. and Borghetti, M. 1995. Interpretation of seasonal changes of xylem embolism and plant hydraulic resistance in Fagus sylvatica. - Plant Cell Environ. 18: 689-696.

Mahall, B. E. et al. 2009. A comparative study of oak (Quercus, Fagaceae) seedling physiology during summer drought in southern California. - Am. J. Bot. 96: 751-761.

Martinez-Ferri, E. et al. 2004. Winter photoinhibition in the field involves different processes in four co-occurring Mediterranean tree species. - Tree Physiol. 24: 981-990.

Martínez-Vilalta, J. et al. 2002. Xylem hydraulic properties of roots and stems of nine Mediterranean woody species. - Oecologia 133: 19-29.

Maseyk, K. S. et al. 2008. Physiology-phenology interactions in a productive semi-arid pine forest. - New Phytol. 178: 603-616.

Maxwell, K. and Johnson, G. N. 2000. Chlorophyll fluorescence - a practical guide. - J. Exp. Bot. 51: 659-668.

Mayr, S. et al. 2006. Frost drought in conifers at the alpine timberline: xylem dysfunction and adaptations. - Ecology 87: 3175-3185.

McCulloh, K. A. et al. 2011. An annual pattern of native embolism in upper branches of four tall conifer species. - Am. J. Bot. 98: 1007-1015.

Meinzer, F. C. et al. 2008. Coordination of leaf and stem water transport properties in tropical forest trees. - Oecologia 156: $31-41$.

Melcher, P. J. et al. 2012. Measurements of stem xylem hydraulic conductivity in the laboratory and field. - Meth. Ecol. Evol. 3: 685-694.

Mitrakos, K. 1980. A theory for mediterranean plant life. - Acta Oecol. Oecol. Plant. 1: 245-252.

Miyazawa, Y. and Kikuzawa, K. 2005. Winter photosynthesis by saplings of evergreen broad-leaved trees in a deciduous temperate forest. - New Phytol. 165: 857-866.

Morecroft, M. D. and Roberts, J. M. 1999. Photosynthesis and stomatal conductance of mature canopy Oak (Quercus robur) and sycamore (Acer pseudoplatanus) trees throughout the growing season. - Funct. Ecol. 13: 332-342.

Nardini, A. and Salleo, S. 2000. Limitation of stomatal conductance by hydraulic traits: sensing or preventing xylem cavitation? - Trees 15: 14-24.

Nardini, A. et al. 2000. Different responses to drought and freeze stress of Quercus ilex L. growing along a latitudinal gradient. - Plant Ecol. 148: 139-147.

Nardini, A. et al. 2011. Refilling embolized xylem conduits: is it a matter of phloem unloading? - Plant Sci. 180: 604-611.

Nardini, A. et al. 2014. The challenge of the Mediterranean climate to plant hydraulics: responses and adaptations. - Environ. Exp. Bot. 103: 68-79.

Neuner, G. and Pramsohler, M. 2006. Freezing and high temperature thresholds of photosystem 2 compared to ice nucleation, frost and heat damage in evergreen subalpine plants. - Physiol. Plant. 126: 196-204.

Ogaya, R. and Peńuelas, J. 2003. Comparative seasonal gas exchange and chlorophyll fluorescence of two dominant woody species in a Holm Oak Forest. - Flora 198: 132-141.

Peguero-Pina, J. J. et al. 2011. Embolism induced by winter drought may be critical for the survival of Pinus sylvestris 
L. near its southern distribution limit. - Ann. For. Sci. 68: 565-574.

Peters, J. et al. 2008. Influence of canopy position, needle age and season on the foliar gas exchange of Pinus canariensis. - Eur. J. For. Res. 127: 293-299.

Pittermann, J. 2010. The evolution of water transport in plants: an integrated approach. - Geobiology 8: 112-139.

Porcar-Castell, A. et al. 2008. Seasonal acclimation of photosystem II in Pinus sylvestris. I. Estimating the rate constants of sustained thermal energy dissipation and photochemistry. - Tree Physiol. 28: 1475-1482.

Pratt, R. B. et al. 2005. Mechanisms for tolerating freezethaw stress of two evergreen chaparral species: Rhus ovata and Malosma laurina (Anacardiaceae). - Am. J. Bot. 92: 1102-1113.

Prieto, P. et al. 2009. Effects of long-term experimental night-time warming and drought on photosynthesis, $F_{\mathrm{v}} / F_{\mathrm{m}}$ and stomatal conductance in the dominant species of a Mediterranean shrubland. - Acta Physiol. Plant. 31: 729-739.

Reich, P. B. et al. 2003. The evolution of plant functional variation: traits, spectra and strategies. - Int. J. Plant Sci. 164: S143-S164.

Ruelland, E. et al. 2009. Cold signalling and cold acclimation in plants. - Adv. Bot. Res. 49: 35-150.

Salleo, S. et al. 2000. Xylem cavitation and hydraulic control of stomatal conductance in laurel (Laurus nobilis L.). - Plant Cell Environ. 23: 71-79.

Schreiber, U. et al. 1994. Chlorophyll fluorescence as a nonintrusive indicator for rapid assessment of in vivo photosynthesis. - In: Schulze, E. D. and Caldwell, M. M. (eds), Ecophysiology of photosynthesis. Springer, pp. 49-70.

Sperry, J. S. 1993. Winter xylem embolism and spring recovery in Betula cordifolia, Fagus grandifolia, Abies balsamera and Picea rubens. - In: Borghetti, J. et al. (eds), Water transport in plants under climatic stress. Cambridge Univ. Press, pp. 86-98.

Sperry, J. S. 1995. Limitations on stem water transport and their consequences. - In: Gartner, B. L. (ed.), Plant stems: physiology and functional morphology. Academic Press, pp. 105-124.

Supplementary material (available as Appendix oik.01526 at $<$ www.oikosjournal.org/readers/appendix $>$ ). Appendix 1.
Sperry, J. S. 2000. Hydraulic constraints on plant gas exchange. - Agric. For. Meteorol. 104: 13-23.

Sperry, J. S. and Tyree, M. T. 1988. Mechanism of water stressinduced xylem embolism. - Plant Physiol. 88: 581-587.

Sperry, J. and Sullivan, J. E. M. 1992. Xylem embolism in response to freeze-thaw cycles and water stress in ring-porous, diffuseporous and conifer species. - Plant Physiol. 100: 605-613.

Sperry, J. S. et al. 1994. Xylem embolism in ring-porous, diffuseporous, and coniferous trees of northern Utah and interior Alaska. - Ecology 75: 1736-1752.

Tognetti, R. et al. 1998. Vulnerability of xylem to embolism in relation to plant hydraulic resistance in Quercus pubescens and Quercus ilex co-occurring in a Mediterranean coppice stand in central Italy. - New Phytol. 139: 437-447.

Tyree, M. T. and Sperry, J. S. 1989. Vulnerability of xylem to cavitation and embolism. - Annu. Rev. Plant Physiol. Plant Mol. Biol. 40: 19-38.

Tyree, M. T. and Cochard, H. 1996. Summer and winter embolism in oak: impact on water relations. - Ann. Sci. For. 53: 173-180.

Valladares, F. and Pearcy, R. W. 1997. Interactions between water stress, sun-shade acclimation, heat tolerance and photoinhibition in the sclerophyll Heteromeles arbutifolia. - Plant Cell Environ. 20: 25-36.

Wang, J. et al. 1992. The relation of foliar phenology to xylem embolism in trees. - Funct. Ecol. 6: 469-475.

White, D. A. et al. 2000. Leaf water relations and stomatal behavior of four allopatric Eucalyptus species planted in Mediterranean southwestern Australia. - Tree Physiol. 20: $1157-1165$.

Whitehead, D. 1998. Regulation of stomatal conductance and transpiration in forest canopies. - Tree Physiol. 18: 633-644.

Willson, C. J. and Jackson, R. B. 2006. Xylem cavitation caused by drought and freezing stress in four co-occurring Juniperus species. - Physiol. Plant. 127: 374-382.

Zar, J. H. 1999. Biostatistical analysis. - Prentice-Hall.

Zimmermann, M. H. 1983. Xylem structure and the ascent of sap. - Springer. 